\title{
Uji Efektivitas Perangkap Feromon Terhadap Hama Oryctes rhinoceros L. dan Intensitas Kerusakan pada Tanaman Kelapa di Desa Latuhalat, Kecamatan Nusaniwe, Pulau Ambon
}

\author{
Betty Sahetapy*, Ester D. Masauna dan Rieske Luhukay \\ ${ }^{1}$ Program Studi Agrotek, Fakultas Pertanian, Universitas Pattimura, Ambon. \\ *Alamat korepondensi: bettysahetapy@gmail.com
}

\begin{abstract}
Effectiveness trial of pheromone traps against Oryctes rhinoceros L. and its damage intensity on coconut tree at Batulahat Village, Nusaniwe District, Ambon Island
\end{abstract}

The research aimed to determine the efficacy of traps containing pheromone in catching the coconut pest, coconut rhinoceros beetle (Oryctes rhinoceros L.) and its effect on reducing the damage severity caused by the pest. The experiment was conducted by observing the damage intensity before treatment and continued with the efficacy testing of the traps containing pheromone (Ethyl 4-methyloctanoate) against the population of the coconut rhinoceros beetle. The damage intensity was measured following the traps treatment. The result demonstrated that the average of damage intensity before and after treatment were $13.33 \%$ and $9.61 \%$, respectively. This indicated the effectiveness of traps in catching the coconut rhinoceros beetle. The number of $O$. rhinoceros caught during the experiment was analysed using quantitative analysis model. The highest number of coconut rhinoceros beetle caught was 9 bettles/ 2 months at traps containing pheromone. Whilst, the number of coconut rhinoceros beetle caught at traps containing pheromone with lamp demonstrated lower number of coconut rhinoceros beetle. Furthermore, the lower damage intensity at the experimental location was categorized as low. This was due to good agricultural practice implemented by the farmer.

Keywords: Coconut, Pheromone, Damage intensity

\begin{abstract}
ABSTRAK
Penelitian ini bertujuan untuk mengetahui keefektifan perangkap feromon dalam memerangkap hama Oryctes rhinoceros L. dan pengaruhnya terhadap intensitas kerusakan yang disebabkan oleh hama tersebut. Penelitian dilakukan dengan menghitung Intensitas Kerusakan (IK) yang disebabkan oleh hama $O$. rhinoceros dan dilanjutkan dengan menguji efektivitas perangkap feromon (Ethyl 4-methyloctanoate) terhadap perkembangan populasi hama tersebut. Intensitas kerusakan dihitung dengan menggunakan formula IK untuk tanaman yang terserang dan yang tidak terserang $O$. rhinoceros sebelum dan sesudah aplikasi feromon. Hasil penelitian menunjukkan rerata IK sebelum dan sesudah aplikasi feromon masing-masing sebesar 13,33\% dan 9,61\%. Terjadi penurunan IK karena efektivitas feromon dapat memerangkap hama O.rhinoceros. Jumlah tangkapan $O$. rhinoceros tiap perlakuan dianalisa dengan model analisis kuantitatif sederhana. Jumlah tangkapan $O$. rhinoceros terbanyak dengan rerata tangkapan 9 ekor/2 bulan atau sama dengan 4,75 ekor/bulan pada perangkap berferomon saja. Sementara perangkap feromon dan lampu menghasilkan jumlah tangkapan hama $O$. rhinoceros yang lebih rendah. Lebih lanjut, rerata IK hama $O$. rhinoceros di desa Latuhalat tergolong kategori ringan karena sistem kultur teknik dari petani setempat sudah dilakukan dengan baik sehingga areal pertanaman kelapa cukup terawat.
\end{abstract}

Kata Kunci: Kelapa, Feromon, Intensitas kerusakan 


\section{PENDAHULUAN}

Kelapa (Cocos nucifera L.) merupakan tanaman perkebunan berupa pohon, berbatang lurus dari famili Palmae. Kelapa disebut juga tanaman serbaguna, karena seluruh bagian tanaman seperti akar, batang, daun, dan buahnya dapat dimanfaatkan untuk kebutuhan industri maupun rumah tangga (Setyamidjaja, 2000). Di Indonesia kelapa menjadi salah satu komoditi tanaman perkebunan penting selain kakao, kelapa sawit, karet, tebu, dan kopi. Berdasarkan data Direktorat Jendral Perkebunan tahun 2015, produksi kelapa di Indonesia pada tahun 2011 sebesar 0,84 ton/ha, tahun 2012 sebesar 0,84 ton/ha, tahun 2013 sebesar 0,83 ton/ha, tahun 2014 sebesar 0,83 ton/ha, dan tahun 2015 sebesar 0,83 ton/ha. Berdasarkan data Dinas Statistik Daerah Tingkat I Maluku tahun 2016, produksi kelapa di Maluku tahun 2011 sebesar 79.723 ton, tahun 2012 sebesar 123.366 ton, tahun 2013 sebesar 95.992 ton, tahun 2014 sebesar 100.459 ton, dan tahun 2015 sebesar 96.534 ton.

Banyak faktor yang mempengaruhi sehingga produksi kelapa menurun dari tahun ke tahun, salah satu faktor tersebut antara lain serangan hama tanaman. Kumbang tanduk (Oryctes rhinoceros L.) merupakan salah satu hama yang paling merusak dan serangannya hampir di seluruh perkebunan kelapa di Indonesia (Lekahena, 2013). O. rhinoceros termasuk serangga nokturnal yang aktif pada malam hari dan tertarik pada cahaya. Imago $O$. rhinoceros menggerek pucuk kelapa pada bagian yang lunak dan mengandung air, dengan demikian pada waktu daun membuka akan berbentuk seperti kipas, pelepah daun menjadi terhambat pertumbuhannya atau mati karena patah setelah daun mulai membuka, tidak terdapat pucuk baru karena kumbang menyerang dan merusak pada bagian penting yakni titik tumbuh. Apabila terjadi serangan yang berat dapat menyebabkan tanaman kelapa menjadi mati (Kartasapoetra, 1993). Wibawanti (2013) menyatakan dengan rerataan jumlah guntingan 0,25-1,50 per pelepah dapat menyebabkan penurunan produksi buah 10\% - 53\%.

Usaha pengendalian $O$. rhinoceros dapat dilakukan secara kultur teknis dengan menebang tanaman yang sudah mati kemudian kayunya dimanfaatkan untuk kayu bakar atau perabot rumah. Pestisida juga digunakan untuk mengendalikan serangga ini, misalnya penyemprotan Aldrin 40\% WP, Toxaphene, BHC puder kadar 0,1 \% (Kartasapoetra, 1993). Menurut Hosang \& Alouw (2005), penggunaan pestisida dinilai berdampak pada pencemaran lingkungan, terbunuhnya makhluk hidup yang bukan sasaran, dan apabila pemberian secara terus menerus menyebabkan $O$. rhinoceros menjadi resisten. Oleh karena itu, perlu diupayakan suatu metode pengendalian yang aman.

Adapun metode aman untuk pengendalian $O$. rhinoceros dan mendukung kegiatan PHT yaitu penggunaan perangkap feromon (Ethyl 4methyloctanoate) (Syakir et al, 2013). Ethyl 4methyloctanoate merupakan senyawa feromon agregasi yang dihasilkan oleh imago $O$. rhinoceros jantan (Hallett et al, 1995; Morin et al, 1996). Metode sintesis dari feromon agregasi $O$. rhinocerosL. telah dikembangkan dan sekarang tersedia dalam kemasan siap pakai dimana formulasi feromon akan menguap secara perlahan untuk menarik O. rhinoceros ke perangkap. Satu kemasan feromon agregasi sintetik (Ethyl 4-methyloctanoate) mampu bertahan tiga bulan di lapangan dengan tingkat keampuhan dalam memerangkap O.rhinoceros mencapai 95\% (Rahutomo, 2008).

Pemanfaatan perangkap feromon dalam pengendalian $O$. rhinoceros sudah dilakukan oleh beberapa negara antara lain Filipina, Malaysia, Srilanka, India, Thailand dan Indonesia (APPC 2005a, 2005b). Rerata kumbang yang terperangkap pada lokasi dengan tingkat serangan ringan adalah 5,6 ekor/ha/bulan sedangkan pada lokasi dengan tingkat serangan berat mencapai 27 ekor/ha/bulan (Allow, 2007). Selain menarik O. rhinoceros feromon agregasi sintetik (Ethyl 4-methyloctanoate) juga dapat menarik kumbang sagu Rhyncophorus feuginneus dan kumbang Xylotrupus gideon dan serangga-serangga lain dari famili Scarabaeidae ke dalam perangkap (Hosang, 1991). Dalam penelitian ini diuji keefektivitasan dari dua jenis perangkap dengan feromon Ethyl 4-methyloctanoate terhadap kumbang tanduk (O. rhinoceros), yang didasarkan dengan pemanfaatan feromon dan sifat serangga yang termasuk serangga noktunal.

\section{BAHAN DAN METODE}

Penelitian ini dilaksanakan di Desa Latuhalat, Kecamatan Nusaniwe, Kota Ambon yang berlangsung pada bulan September-November 2016. Penelitian dilakukan di lahan petani yang ditanami kelapa. Pada penelitian ini diuji dua jenis perangkap terhadap hama $O$. rhinoceros,yaitu $\mathrm{PF}=$ Perangkap dengan feromon (Ethyl 4-methyloctanoate) PFL = Perangkap dengan feromon (Ethyl 4methyloctanoate) dan lampu pijar (40 watt).

Pelaksanaan Penelitian meliputi beberapa tahapan yaitu: 
1. Peninjauan lokasi

Survei lokasi penelitian yang bertujuan untuk mengetahui keadaan lokasi yang dijadikan sebagai tempat pelaksanaan penelitian, sekaligus menghitung intensitas kerusakan awal pada desa sampel.

2. Pembuatan Perangkap

a) Perangkap dengan feromon (Ethyl 4mathyloctanoate). Perangkap dengan feromon (Ethyl 4-mathyloctanoate) terdiri dari dua bagian yaitu (1) Ember plastik sebagai perangkap. Ember plastik ukuran 6 liter, tutup ember dilubangi sebanyak 5 lubang (diameter $55 \mathrm{~mm}$ ) diletakkan terbalik, pada dasar ember plastik dibuat 4 lubang (diameter $2 \mathrm{~mm}$ ) untuk pembuangan air; (2) Feromon (Ethyl 4mathyloctanoate) dikeluarkan dari kemasan, dililit pada kawat kecil sepanjang $10 \mathrm{~cm}$, dan dikaitkan pada tutup ember plastik yang diletakkan terbalik.

b)Perangkap dengan feromon (Ethyl 4mathyloctanoate) dan lampu. Perangkap dengan feromon (Ethyl 4-mathyloctanoate) dan lampu terdiri dari tiga bagian yaitu (1) Lampu pijar (40 watt), digantung pada bagian atas ember; (2) Ember plastik sebagai perangkap yang berukuran 6 liter, tutup ember dilepas, pada bagian dalam ember dioleskan lem, dan dasar ember dibuat 4 lubang (diameter $2 \mathrm{~mm}$ ) untuk pembuangan air; (3) feromon (Ethyl 4-mathyloctanoate) dikeluarkan dari kemasan, dililit pada kawat kecil sepanjang $10 \mathrm{~cm}$, dan dikaitkan pada tutup ember plastik yang diletakkan terbalik.

3. Pemasangan Perangkap

Kedua jenis perangkap digantung pada ketinggian 4 meter dengan jarak antar perangkap 250 meter.

4. Waktu Pengamatan

a) Populasi $O$. rhinoceros

Pengamatan dilakukan 7 hari setelah pemasangan perangkap, selama 8 minggu, dan dilakukan pada pukul 09.00-14.00 WIT. Sampel diperoleh dengan cara mengambil kumbang yang tertangkap pada masingmasing perlakuan.

b)Perbandingan imago $O$. rhinoceros yang tertangkap

Pengamatan dilakukan setelah sampel diperoleh dengan membandingkan ciri-ciri fisik setiap imago $O$. rhinoceros yang tertangkap.

\section{Variabel Pengamatan}

Variabel pengamatan meliputi jumlah tangkapan imago $O$. rhinoceros (ekor) tiap perlakuan, jumlah tangkapan imago $O$. rhinoceros jantan dan imago O. rhinoceros betina (ekor) tiap perlakuan dan intensitas kerusakan (IK) akibat serangan kumbang $O$. rhinoceros sebelum perlakuan dan sesudah perlakuan.

\section{Analisis Data}

Data yang diperoleh dilakukan tabulasi dan dihitung rerata populasi imago $O$. rhinoceros dengan menggunakan analisis kuantitatif sederhana:

Keterangan:

$$
\mu=\frac{\sum x_{i}}{n}
$$

$\mu$ : Rata-rata populasi imagoO. rhinoceros L.per perlakuan

$x_{i}$ : Jumlah kumbang yang tertangkap per ulangan

$\mathrm{n}$ : Banyaknya ulangan

Penghitungan Intensitas Kerusakan akibat serangan kumbang $O$. rhinoceros pada tanaman kelapa dengan cara menghitung seluruh pelepah daun kelapa yang terserang dan yang tidak terserang dengan rumus sebagai berikut (Natawigena, 1989),

$$
P=\frac{\sum(n \times v)}{Z \times N} \times 100 \%
$$

\section{Keterangan:}

$\mathrm{P}=$ Intensitas kerusakan

$\mathrm{n}=$ Jumlah pelepah daun tiap kategori serangan

$\mathrm{v}=$ Nilai skala dari tiap kategori serangan

$\mathrm{Z}=$ nilai skala dari kategori serangan tertinggi

$\mathrm{N}=$ Jumlah pelepah daun yang diamati tiap pohon

Kategori Serangan (v)

0 : tidak ada gejala serangan baru

1 : serangan atau kerusakan kurang dari 5\%

2 : serangan baru atau kerusakan $5-10 \%$

3 : serangan baru dengan kerusakan tanaman $10-$ $25 \%$

4 : serangan baru dengan kerusakan $25-50 \%$

5 : serangan berat dengan kerusakan lebih dari 50\%.

\section{HASIL DAN PEMBAHASAN}

\section{Jumlah Tangkapan Kumbang Kelapa (O. rhinoceros L.) Tiap Perlakuan}

Selama observasi dilakukan di lokasi penelitian, hama yang menyerang tanaman kelapa teridentifikasi sebagai $O$. rhinoceros dan Sexava. Hal 
ini terlihat dari gejala kerusakan pada tanaman kelapa miliki petani (Gambar 1).

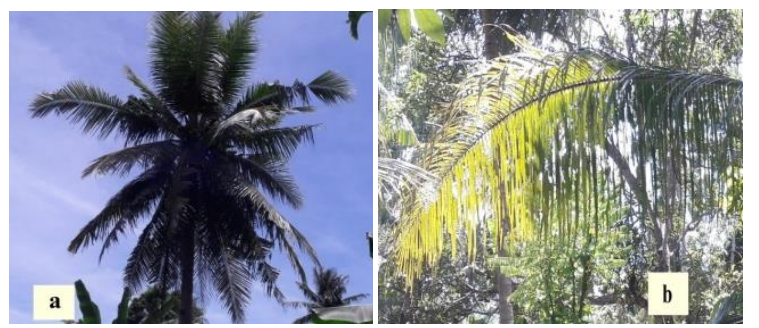

Gambar 1. Gejala serangan hama tanaman kelapa: (a) Hama O. rhinoceros dan (b) Hama sexava.

Dari hasil pengamatan selama dua bulan, jumlah tangkapan $O$. rhinoceros tiap perlakuan dapat dilihat pada Gambar 2. Rerata tangkapan $O$. rhinoceros terbanyak berjumlah 9 ekor/2bulan atau sama dengan 4,375 ekor/bulan, diikuti perlakuan perangkap feromon dan lampu (2,375 ekor/bulan). Rerata tangkapan imago O. rhinoceros terbanyak yakni 4,375 ekor/bulan, hal ini dikarenakan intensitas kerusakan pada lokasi pengamatan masuk dalam kategori ringan yakni antara 13,33-16,66 persen. APCC (2006), menyatakan dengan penggunaan feromon dapat menurunkan populasi $O$. rhinoceros di lapangan 5-27 ekor/ha/bulan. Alouw (2007), menambahkan pada lokasi dengan tingkat serangan ringan dengan penggunan feromon rerata kumbang yang tertangkap adalah 5,6 ekor/ha/bulan sedangkan pada lokasi dengan tingkat kerusakan berat mencapai 27 ekor/ha/bulan.

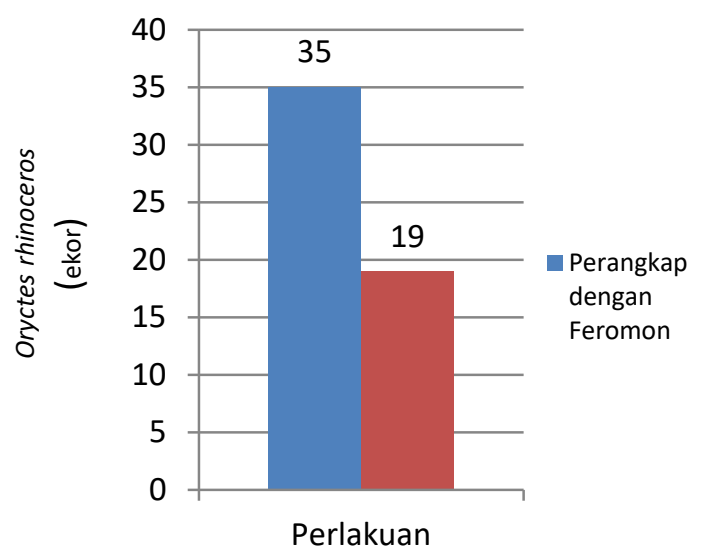

Gambar 2. Rerata tangkapan kumbang kelapa ( $O$. rhinoceros) tiap perlakuan.

Jenis perangkap dengan feromon, memerangkap $O$. rhinoceros dengan jumlah terbanyak (35 ekor) dibandingkan perangkap dengan feromon dan lampu. Hal ini dikarenakan, feromon sintetik (ethyl 4-methylactonoat) yang digunakan pada perangkap merupakan jenis feromon agregasi. Feromon agregasi merupakan bahan kimia yang dikeluarkan oleh serangga untuk menarik serangga jantan dan betina untuk berkumpul, untuk mencari pasangan dan dilanjutkan dengan kopulasi, mempertahankan diri terhadap serangan predator dan untuk mengatasi resistensi tanaman inang dengan jalan menyerang secara massal (Oka, 1998).

Penggunaan perangkap dengan feromon agregasi sintetik (ethyl 4-methylactonoat) ini dapat menarik kumbang jantan dan betina serta memiliki tingkat keampuhan dalam memerangkap $O$. rhinoceros mencapai 95\% (Rahutomo, 2008). Satu kemasan feromon agregasi sintetik (ethyl 4methylactonoat) dapat digunakan untuk luasan 1 hektar atau 2 hektar. Utomo dkk. (2006), merekomendasikan untuk perangkap massal ialah dengan meletakan satu perangkap untuk 2 hektar, dan pada populasi $O$. rhinoceros yang tinggi, aplikasi feromon diterapkan satu perangkap per hektar.

Jenis perangkap dengan feromon dan lampu, memerangkap $O$. rhinoceros jumlah yang sedang ( 19 ekor). Rendahnya jumlah O. rhinoceros $\mathrm{L}$ yang terperangkap pada perlakuan ini dapat disebabkan oleh penggunaan jenis lampu. Cahaya mempengaruhi perilaku serangga. Salah satu tanggapan yang paling khas terhadap cahaya adalah phototaxis (Jander, 1963). Lampu chiyoda 40 watt yang digunakan merupakan jenis lampu pijar. Lampu pijar memancarkan cahaya lemah pada spektrum ultraviolet (UV). Lemahnya spektrum ultraviolet yang dipancarkan oleh lampu menyebabkan terjadinya penurunan daya tarik dari lampu tersebut terhadap serangga. Penurunan daya tarik lampu terhadap $O$. rhinoceros terlihat jelas pada perangkap dengan lampu. Peletakan perangkap yang berdekatan dengan pemukiman diduga juga mempengaruhi jumlah tangkapan $O$. rhinoceros pada delapan minggu pengamatan.O. rhinoceros diduga menuju rumah warga yang memiliki pencahayaan yang baik. Hal ini didukung dengan adanya laporan dari warga yang berdekatan dengan tempat peletakan perangkap sering ditemukan $O$. rhinoceros.

Selama delapan minggu pengamatan hasil tangkapan O. rhinoceros tiap perlakuan mengalami fluktuasi. Puncak banyaknya $O$. rhinoceros yang tertangkap yakni pada jenis perangkap dengan feromon (PF) terjadi pada minggu ke-4 yang mencapai hasil tangkapan sebanyak 10 ekor (Gambar 3). Jumlah $O$. rhinoceros yang terperangkap mengalami fluktuasi dan semakin lama semakin berkurang. Penurunan jumlah $O$. 
rhinoceros yang terperangkap signifikan terjadi pada jenis perangkap dengan feromon. Hal ini disebabkan oleh penggunaan feromon yang berbentuk cair akan berkurang kuantitasnya akibat penguapan, sehingga bau (senyawa kimia) dari feromon perlahan-lahan akan hilang dan tidak berpengaruh lagi pada $O$. rhinoceros.

Hal tersebut di atas diperkuat oleh pendapat Rahutomo (2008), yang menyatakan bahwa senyawa kimia etil 4-methylactonoat pada feromon agregasi sintetik hanya mampu bertahan selama 3 bulan di lapangan, jika disimpan terlalu lama akan habis menguap. Alouw (2007), menambahkan keberhasilan penggunaan feromon dipengaruhi oleh penguapan bahan kimia, kepekaan penerima, jumlah dan bahan kimia yang dihasilkan dan dibebaskan persatuan waktu, kecepatan angin dan temperatur. Suhu yang tinggi dan kecepatan angin yang sesuai mempercepat penguapan feromon untuk menyebar sehinggga lebih cepat untuk merangsang $O$. rhinoceros untuk mencari asal sumber feromon tersebut (Herman, 2012). Berkurangnya populasi $O$. rhinoceros pada areal pengamatan akibat penangkapan juga sangat mempengaruhi jumlah tangkapan $O$. rhinoceros tiap minggunya.

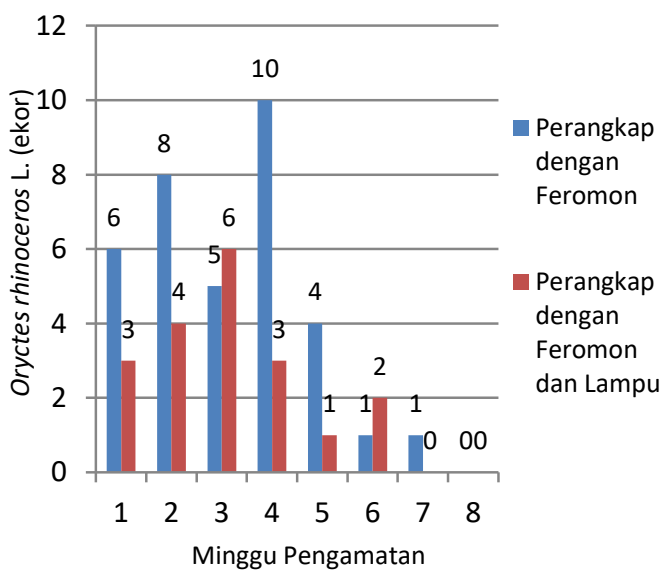

Gambar 3. Jumlah tangkapan O. rhinoceros (ekor) tiap minggu pengamatan

Pada saat penelitian ditemukan juga larva $O$. rhinoceros, larva ditemukan pada batang kelapa yang telah membusuk dengan ciri-ciri larva berwarna putih, memiliki tiga pasang kaki semu, dan bagian kepala berwarna coklat kemerah-merahan, selain itu tubuh larva terdapat bulu-bulu pendek berwarna putih (Gambar 4). Hal ini sesuai dengan pendapat Kartasapoetra (1993) dan Setyamidjaja (2000), bahwa larva O. rhinoceros memiliki 3 pasang kaki semu, kepalanya berwarna coklat kemerah-merahan, badannya berbulu pendek. Pada lahan petani dijumpai juga tumpukan-tumpukan kulit kelapa, sisa-sisa batang kelapa yang membusuk, serasah-serasah tanaman, dan banyak ditumbuhi gulma. Kondisi kebun demikian sangat baik bagi tempat berkembangbiakan $O$. rhinoceros terutama pada stadia telur dan larva. Setyamidjaja (2000), menyatakan larva $O$. rhinoceros hidup pada sisa-sisa tumbuhan yang membusuk, kotoran ternak, timbunan sampah, sisa-sisa pengolahan hasil pertanian (sekam padi, ampas tebu, serbuk gergaji) atau batang kelapa yang membusuk.

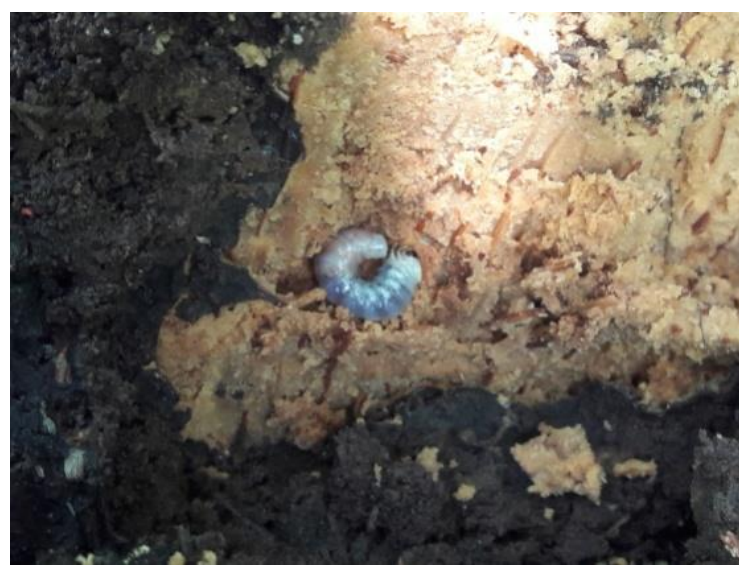

Gambar 4. Larva O. rhinocerosyang ditemukan pada batang kelapa yang membusuk.

Jumlah Tangkapan Imago Kumbang Kelapa ( $O$. rhinoceros L.) Jantan dan Betina (Ekor) Tiap Perlakuan

Hasil analisis terhadap jumlah hama tanaman kelapa yang tertangkap selama masa percobaan, diperoleh perbandingan tangkapan imago $O$. rhinocerostiap (Gambar 5). Jenis perangkap dengan feromon dan jenis perangkap dengan feromon dan lampu memerangkap $O$. rhinoceros betina (ekor) dengan jumlah yang lebih banyak dibandingakan $O$. rhinoceros jantan (ekor), dengan perbandingan (27:9, dan 14 : 5 atau 75\% : $25 \%)$. Jenis perangkap dengan feromon dan jenis perangkap dengan feromon dan lampu merupakan jenis perangkap yang menggunakan feromon agregasi sintetik dengan senyawa kimia ethyl 4 methylactonoat. Ethyl 4-methyloctanoate merupakan senyawa feromon agregasi yang dihasilkan oleh imago O. rhinoceros jantan (Hallett et al, 1995 dan Morin et al, 1996). Maka dengan penggunaan feromon ini akan lebih menarik serangga betina. Hal ini diperkuat oleh Sudharto et 
al. (2003), yang menyatakan feromon agregasi sintetik (Ethyl 4-methyloctanoate) menarik 69-79\% imago betina sedangkan imago jantan hanya 21$31 \%$.

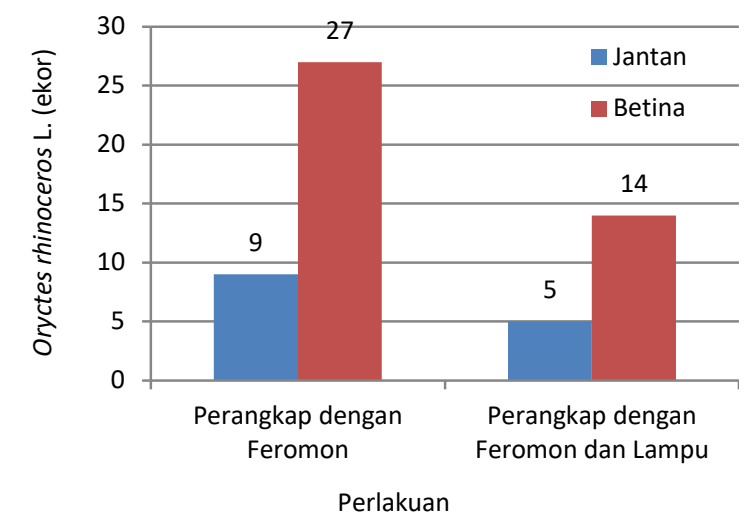

Gambar 5. Tangkapan imago kumbang ( $O$. rhinoceros) jantan dan betina (ekor) tiap perlakuan.

Penggunaan feromon dapat mengakibatkan penurunan populasi $O$. rhinoceros di lapangan pada generasi berikutnya, hal ini disebabkan oleh adanya perubahan laju kelahiran. Salah satu faktor utama penentu laju kelahiran adalah rasio seks. Rasio seks pada kebanyakan serangga populasi adalah 1:1, jantan terhadap betina (Hadi, 2009). Namun dengan penggunaan feromon terjadi perubahan rasio seks di lapangan yakni menjadi 2:1 atau 3:1 jantan terhadap betina, dikarenakan feromon menarik $69-79 \%$ imago betina sedangkan imago jantan hanya 21-31\%. Berkurangnya individu imago betina di lapangan dapat mengakibatkan penurunan kelahiran individu baru, dikarenakan terjadi gangguan pada proses mating (perkawinan serangga). Diperkuat oleh Hadi (2009) yang menyatakan bahwa dengan adanya perubahan proposi imago betina di lapangan menyebabkan perubahan laju kelahiran.

\section{Intensitas Kerusakan}

Rerata Intensitas Kerusakan (IK) akibat serangan hama $O$. rhinoceros di lokasi penelitian rata-rata $13,33 \%$ (Tabel 1). Intensitas kerusakan tersebut tergolong ke dalam kategori serangan ringan. Menurut Kilmaskossu \& Nerokouw (1993) intensitas serangan kumbang $O$. rhinoceros ringan $<40 \%$, intensitas serangan sedang $<60 \%$, dan intensitas serangan berat $>61 \%$. Pada lokasi penelitian sanitasi kebun cukup diperhatikan karena kebun dekat dengan pemukiman penduduk, sehingga berpengaruh juga terhadap perkembangan populasi kumbang $O$. rhinoceros. Intensitas
Kerusakan awal sebesar 13,33\% ditemukan pada lokasi sebelum diberi perangkap dengan Feromon. Setelah diberi perlakuan perangkap dengan feromon, IK menurun menjadi 9,61\%.

Tabel 1. Intensitas Kerusakan (IK) tanaman kelapa akibat serangan hama $O$. rhinoceros di Desa Latuhalat sebelum dan sesudah perlakuan.

\begin{tabular}{ccc}
\hline \multirow{2}{*}{ Sampel } & \multicolumn{2}{c}{ Rata-rata IK (\%) } \\
\cline { 2 - 3 } & Sebelum perlakuan & $\begin{array}{c}\text { Setelah } \\
\text { perlakuan }\end{array}$ \\
\hline 1 & 18.87 & 12.32 \\
2 & 15.07 & 10.22 \\
3 & 12.61 & 8.52 \\
4 & 11.22 & 9.78 \\
5 & 17.25 & 10.86 \\
6 & 13.31 & 9.02 \\
7 & 5.37 & 6.29 \\
8 & 12.83 & 9.71 \\
9 & 14.99 & 9.31 \\
10 & 11.78 & 10.05 \\
\hline Rata-rata & 13,33 & 9,61 \\
\hline
\end{tabular}

\section{KESIMPULAN}

Jenis perangkap yang paling efektif terhadap kumbang tanduk (O. rhinoceros) adalah perangkap dengan feromon. Perlakuan perangkap dengan feromon mampu menurunkan intensitas kerusakan akibat serangan $(O$. rhinoceros) dari 13,33 persen menjadi 9,61persen.

\section{DAFTAR PUSTAKA}

Alouw, JC. 2007. Feromon dan pemanfaatannya dalam penengalian hama kumbang kelapa Oryctes rhinoceros (Coleoptera: Scarabaeidae). Buletin Palma 32: 12-21.

Badan Pusat Statistik, 2016. Maluku Dalam Angka Tahun 2016.

Direktorat Jendral Pekebunan, 2015. Statistik Pekebunan Kelapa Tree Crop Estate Statisties Of Indonesia 2014-2016.

Hadi, MH, U Tarwotjo, dan R Rahadian. 2009. Biologi Insekta Entolomogi. Graha Ilmu. Yogyakarta. $162 \mathrm{p}$.

Hallett, RH, AL Perez, G Gries, R Gries, HD Pierce Jr, J Yue, AC Oehlschlager, LM Gonzalez, and JH Borden. 1995. Aggregation pheromone of the coconut rhinoceos beetle, Oryctes rhinoceros_L. 
(Coleoptera: Scarabaeidae). Journal of Chemical Ecology 21: 1549-1570.

Herman, JH, Laoh, dan D Salbiah. 2012. Uji tingkat ketinggian perangkap feromon untuk mengendalikan kumbang tanduk Oryctes rhinoceros_L_L. (Coleoptera: Scarabeidae) pada tanaman kelapa sawit. Universitas Riau. http://repository.unri.ac.id/xmlui/handle/12 3456789/1624. Diakses: 29 Juli 2016.

Hosang, MLA, dan Salim. 2014. Penekanan populasi Oryctes rhinoceros dan Rhynchophorus ferrugineus dengan perangkap feromon. Prosiding Konferensi Nasional Kelapa VII. 21-22 Mei 2014, Jambi, Indonesia. pp 65-72.

Kartasapoetra, AG. 1993. Hama Tanaman Pangan dan Perkebunan. Bumi Aksara. Jakarta. pp 165-168.

Kilmaskossu STEM, and JP Nero-kouw. 1993. Inventory of forest damage at Faperta Uncen experiment gardens in Manokwari Irian Jaya Indonesia. Proceedings of the Symphosium on Biothecnological and environmental Approaches to Forest and Disease Management. Bogor (ID): SEAMEO BIOTROP.

Natawigena, H. 1989. Pestisida dan Kegunaannya. Bandung: CV Armico.

Lekahena, R. 2013. Pengenalan dan pengendalian hama Oryctes sp dengan jamur Metharizium_anisopliae, BBPPTP Ambon Direktorat Jendral Perkebunan Kementerian Pertanian. http://ditjenbun.petanian.go.id/bbpptpambo $\mathrm{n} \quad$ /ber ita-188-pengenalan-dan- pengendalian-hama-oryctes-sp-denganjamur-me tharizium-anisopliae.html. Diakses: 06 Agustus 2016.

Morin, JP, D Rochat, C Malosse, M Lettee, R Desmier de Chenon, $\mathrm{H}$ Wiwbo, and $\mathrm{C}$ Descoins. 1996. Ethyl 4-methyloctanoate, major component of male pheromone in Oryctes rhinoceros (L.) (Coleoptera, Dynastidae). Journals Comptes Rendus De l'Academic Sciences 319: 595-602.

Rahutomo, S. 2008. Feromonas Ampuh Basmi Hama Kumbang Sawit. Indonesia, mapiptek. E-Magazine, edisi 17 April 2008, Jakarta.

Setyamidjaja, D. 2000. Bertanam Kelapa. Kanisius. Yogyakarta. $120 \mathrm{p}$.

Sudharto PS, and P Guritno. 2003. Biological control of oilpalm nettle caterpillars in Indonesia: review of research activities in Indonesia Oil Palm Research Institute (IOPRI). Prooceedings of the PIPOC, International Palm Oil Congress pp 362371.

Utomo, C, T Herawan, dan Susanto A. 2007. Feromon: era baru pengendalian hama ramah lingkungan di perkebunan kelapa sawit. Jurnal Penelitian Kelapa Sawit, 15(2):69-82.

Wibawanti, R. 2013. Upaya Pengendalian Kumbang Kelapa (Oryctes rhinoceros) di Yogyakarta, Direktorat Jendral Perkebunan Kementerian Pertanian. http://ditjenbun.pertanian.go.id/perlindung an/berita-216-upayapengendali ankumbang-kelapa-oryctes-rhinoceros-diyogyakarta.html. Diakses: 29 Juni 2016. 